\title{
Desiccation-resurrection linked antioxidant machinery of a moss species Campylopus flexuosus (Hedw.) Bird.
}

\author{
Usha S. S. \\ Department of Botany, S N College, Chempazhanthy, Thiruvananthapuram - 695587 (Kerala), \\ India \\ Remya Krishnan* \\ Post-Graduate Department and Research Center of Botany, Mahatma Gandhi College, \\ Thiruvananthapuram (Kerala), India \\ Murugan K. \\ Centre for Innovation in Science and Social Action (CISSA), Phytotech (Kerala), India \\ ${ }^{*}$ Corresponding author. Email: drrkbotany2020@gmail.com
}

\section{How to Cite}

\section{Article Info}

https://doi.org/10.31018/ jans.v13i4.3112

Received: October 20, 2021

Revised: November 29, 2021

Accepted: December 2, 2021

Usha, S. S. et al. (2021). Desiccation-resurrection linked antioxidant machinery of a moss species Campylopus flexuosus (Hedw.) Bird. Journal of Applied and Natural Science, 13(4), 1407 - 1413. https://doi.org/10.31018/jans.v13i4.3112

\begin{abstract}
Dehydration and rejuvenation during rehydration is the salient feature of certain plants which can withstand drought. The present study was undertaken to justify the tolerance capacity of Campylopus flexuosus, the moss of the Ponmudi belts of Thiruvananthapuram, against dehydration followed by rehydration. Fresh leafy plants of $C$. flexuosus were hydrated, afterwards dried, and rehydrated under in vitro environment. In the course of loss of water from cells, the relative water content of desiccated thallus was reduced after $4 \mathrm{~h}$ with intense inward curling. Upon rehydration, the RWC was regained $85 \%$ of its initial water content within hours. The rehydrated thallus showed the normal morphology. Photosynthetic parameters like chlorophyll b (1.01 to $1.56 \mu \mathrm{g} \mathrm{g}-1$ ), and total carotenoid $(0.251$ to $0.514 \mu \mathrm{g} \mathrm{g}-1)$ increased remarkably in the desiccated state. Superoxide radical $\left(\mathrm{O}_{2}-\right)$ content increased $(11.4 \mathrm{nmol} / \mathrm{g} \mathrm{FW})$, resulting in an oxidative burst during desiccation. Consequently, antioxidant enzymes such as catalase $(0.369 \mathrm{U} \mathrm{mg}$ protein -1$)$, superoxide dismutase ( 2.68 to $6.02 \mathrm{Units} \mathrm{mg}-1)$, peroxidase $(0.12 \mu \mathrm{mol}$ min-1 g-1 protein) and glutathione reductase ( 312 Units mg-1 protein) activities were up-regulated in the desiccated thallus to ameliorate oxidative damage. Increased malondialdehyde $(1.08 \mathrm{nmol} \mathrm{g}-1 \mathrm{FW})$ content during desiccation substantiates membrane damage and loss of its integrity. During desiccation, the osmolytes sucrose and proline (27.6 and $2.57 \mu \mathrm{mol} / \mathrm{g} \mathrm{FW} \mathrm{re}-$ spectively) were enhanced to maintain cell structure integrity. After rehydration, biochemical and morphological properties were maintained similar to hydrated conditions. Thus, the study reflects the unique adaptations of the moss to tide over desiccation tolerance.
\end{abstract}

Keywords: Antioxidant enzymes, Desiccation, Photosynthetic pigments, Proline, Resurrection, Tolerance

\section{INTRODUCTION}

Desiccation tolerance (DT) is the adaptive feature to dry and withstands intracellular water level $>90 \%$. It is regulated by multiple genes via proteins (Hassan et al., 2017). Many of the angiosperms and pteridophytes are tolerant to desiccation, i.e., they withstand drying up to 10-20\% of their dry weight and recover metabolism by rehydration (Yathisha et al., 2020). According to Phylogenetic and ecological studies desiccation tolerance is a primitive character of land plants, which lost in the course of evolution of the homoiohydric vascular-plant shoot system, and retained in spores, pollen or seeds, and re-evolved in resurrection plants. In higher plants, anti-oxidant mechanisms play a major role in unravelling tolerance to desiccation (Banupriya et al., 2020). Water stress results in the accumulation of proline in plants, hydration of the leaves lead to the decline of proline. Resurrection plants show peculiar mechanisms to protect their cell membrane (Ahanger and Siddique, 2021). Generally, desiccation tolerance was analysed and documented mostly in flowering plant groups and ferns.

The physiology of bryophytes differs from that of vascular plants. Non-vascular plants like bryophytes, the leafy shoots equilibrate rapidly with the water potential in their surroundings and tend to be either fully hydrated or desiccated and metabolically inactive (Banupriya 
et al., 2020). Bryophytes show poikilohydry and desiccation tolerance that is the optimal pattern of adaptation at their scale and, possess water content equivalent to that of their environment. Bryophytes are considered to be desiccation-tolerant plants, i.e., capable of reviving from an air-dry state (de Carvalho et al., 2019). According to Gao et al. (2018), most bryophytes can survive -20 to $-40 \mathrm{MPa}$ desiccation for short durations, which is beyond the range that most crop species can withstand. $1 \%$ out of total bryophyte species have been experimentally determined to be desiccation tolerant (Wood, 2007). In this scenario, the present study was targeted in Campylopus flexuosus, a moss species, to understand the biochemical, morphological and physiological adaptions to survive and recover from the process of desiccation-resurrection.

\section{MATERIALS AND METHODS}

The plant species selected was $C$. flexuosus, a moss of the family Dicranaceae. It is dioecious, and olive-green grows as tufts with size varied to $1-10 \mathrm{~cm}$. It is hairy and dichotomously branched. Leaves erect, flexuose, when dry $\pm 6 \mathrm{~mm}$ long, lanceolate- subulate and a gradual wider base.

\section{Relative water content (RWC)}

Fresh and healthy thallus was hydrated until fully saturated and had no further weight gain. Fully hydrated thalli were desiccated (air dry) to lose water under room temperature until no further weight loss occurred. Subsequently, the desiccated thalli were rehydrated till no further weight gain. Fully hydrated, desiccated and rehydrated thalli were ground using liquid nitrogen and stored at $-80^{\circ} \mathrm{C}$ for the biochemical and physiological analysis. The percentage of RWC was calculated as the difference between fresh to dry weight (Banupriya et al., 2020).

\section{Chlorophyll and carotenoid contents}

$0.5 \mathrm{~g}$ of fully hydrated, desiccated and rehydrated C.flexuosus tissues were homogenized using liquid nitrogen. The samples were grounded using $10 \mathrm{ml}$ of $80 \%$ acetone, the crude extract was centrifuged at $3,000 \mathrm{~g}$ for $5 \mathrm{~min}$ and the supernatant was collected. The OD of the supernatant was read at $663.6 \mathrm{~nm}$, $646.6 \mathrm{~nm}$, and $440.5 \mathrm{~nm}$ using a Spectrometer. The total chlorophyll and carotenoid contents were quantified using the methodology of Porra et al. (1989). The results were expressed on the basis of $\mu \mathrm{g} \mathrm{chl/g}$ dry sample.

\section{Quantitative assay of superoxide radical $\left(\mathrm{O}_{2}{ }^{-}\right)$}

One gram fully hydrated, desiccated and rehydrated thalli were extracted with $100 \mathrm{mM}$ potassium phosphate buffer $-\mathrm{pH}$ 7.2. To the reaction mixture, $500 \mu \mathrm{l}$ of $2 \mathrm{mM}$ nitro blue tetrazolium was mixed and incubated for 20 min. The reaction was arrested by adding $\mathrm{ml}$ of 1.4-dioxan. The tubes were heated at $70^{\circ} \mathrm{C}$ in a water bath for $15 \mathrm{~min}$, it was then cooled, and centrifuged at $2,000 \mathrm{~g}$ for $10 \mathrm{~min}$ and the OD of the supernatant was recorded at $540 \mathrm{~nm} \cdot \mathrm{O}_{2}{ }^{-}$was calculated as per the protocol of Fontana and Rosei (2001) and was expressed as $\mu \mathrm{mol} / \mathrm{g} \mathrm{FW}$.

\section{Quantification of soluble sugar and starch}

To one gram of fully hydrated, desiccated and rehydrated C.flexuosus thalli ice-cold $1 \mathrm{M}$ perchloric acid was added and ground, the slurry was centrifuged at 12,000 $\mathrm{g}$ for $2 \mathrm{~min}$ at $4^{\circ} \mathrm{C}$. $5 \mathrm{M}$ Potassium carbonate was added for neutralizing the supernatant and was precipitated with potassium perchlorate. The supernatant was used to estimate sucrose, while the pellet was used to estimate starch. Sucrose and starch were estimated by following the protocol of Banupriya et al. (2020) and were expressed as $\mu \mathrm{mol} / \mathrm{G} \mathrm{FW}$.

\section{Quantification of proline}

$1 \mathrm{~g}$ of fully hydrated, desiccated and rehydrated thalli was used for estimating proline content (Yathisha et al.,2020). The thalli were homogenized using 3\% sulfosalicylic acid. And after $72 \mathrm{~h}$, the released proline was recorded. For the purpose, the homogenate was centrifuged at $3,000 \mathrm{~g}$ and the obtained supernatant was boiled for $1 \mathrm{hr}$ after treating with acetic acidninhydrin, and OD was read at $520 \mathrm{~nm}$ and was expressed as $\mathrm{mg} \mathrm{g}^{-1} \mathrm{dw}^{-1}$.

\section{Quantification of lipid peroxidation (LPX)}

Lipid peroxidation was measured according to the protocol of Li et al. (2000), using 2-thiobarbituric acid (TBA). $0.5 \mathrm{~g}$ of fully hydrated, desiccated and rehydrated C.flexuosus thalli was homogenised using $2 \mathrm{ml}$ of $0.25 \%$ TBA made in $10 \%$ Trichloroacetic acid. Crude extract was heated at $95^{\circ} \mathrm{C}$ in a boiling water bath for $30 \mathrm{~min}$ and cooled suddenly. It was centrifuged at $10,000 \mathrm{~g}$ for 10 minutes. The collected supernatant was used for reading OD at 532 and $600 \mathrm{~nm}$. LPX level was expressed as $\mathrm{nmol} \mathrm{g}{ }^{-1} \mathrm{FW}$ of malondialdehyde (MDA), calculated using an extinction coefficient of $155 \mathrm{mM}$ $\mathrm{cm}^{-1}$.

\section{Antioxidant enzymes assay}

Different antioxidant enzymes like superoxide dismutase (SOD), catalase (CAT), peroxidase (POX) and glutathione reductase (GR) were assayed in fully hydrated, desiccated and rehydrated thalli of C.flexuosus. For assay of SOD and CAT), the tissues were grounded separately in $6 \mathrm{ml}$ of extraction buffer-1 containing $50 \mathrm{mM}$ phosphate-buffered saline (PBS), pH 7.8 and for assay of POX and GRb $6 \mathrm{ml}$ extraction buffer-2 (100 $\mathrm{mM}$ PBS), $\mathrm{pH} 7.0$ at $4^{\circ} \mathrm{C}$. The homogenates were cen- 
trifuged for $20 \mathrm{~min}\left(15,000 \mathrm{~g}\right.$ at $\left.4^{\circ} \mathrm{C}\right)$. NBT was used as a control to estimate SOD. The reaction solution of SOD consisted 50 mM PBS ( $\mathrm{pH} 7.8$ ), 130 mM methionine, $20 \mu \mathrm{M}$ riboflavin, $750 \mu \mathrm{M}$ NBT chloride, $100 \mu \mathrm{M}$ EDTA-Na2+, and $0.1 \mathrm{ml}$ of enzyme extract. The reaction mixture was incubated under fluorescent light with an intensity of $50 \mu \mathrm{mol} \mathrm{m}-2 \mathrm{~s}-1$ for 20 minutes. The OD was read at $560 \mathrm{~nm}$. SOD activity was expressed in Units mg-1 protein.

CAT activity was measured according to the methodology of Change and Maethly (1995), analysing the rate of disappearance of $\mathrm{H}_{2} \mathrm{O}_{2}$. The absorbance at A240 was recorded, and the activity was expressed as the number of $\mu \mathrm{mol}$ of $\mathrm{H}_{2} \mathrm{O}_{2}$ catalyzed by a unit of CAT per min. The activity of POX was measured using the reaction a mixture containing $100 \mathrm{mM}$ PBS (pH 7.0), $50 \mathrm{mM}$ o-methoxyphenol, $40 \mathrm{mM} \mathrm{H}_{2} \mathrm{O}_{2}$, and $0.1 \mathrm{ml}$ of enzyme extract and results were expressed in $\mu \mathrm{mol}$ min-1 g-1 protein.

According to the method of Halliwell and Foyer (1978), GR activity was determined. The reaction mixture consisted of $0.2 \mathrm{mM}$ nicotinamide adenine dinucleotide phosphate hydrogen, $50 \mathrm{mM}$ Tris- $\mathrm{HCl}, 0.5 \mathrm{mM}$ Glutathione disulfide and $5 \mathrm{mM} \mathrm{MgCl}_{2}$. OD was noted at 340 $\mathrm{nm}$, within $3 \mathrm{~min}$, the number of $\mu \mathrm{mol}$ of NADPH oxidization and was expressed in Units mg-1 protein.

\section{Statistical analysis}

The results obtained were subjected to one-way analysis of variance. The significant differences among the test groups ( $p \leq 0.05$ ) were obtained by Tukey's honestly significant difference post hoc test using SPSS software (SPSS20.0, SPSS Inc., Chicago IL). The values shown were the means \pm standard deviations (SD) of three independent replicates.

\section{RESULTS AND DISCUSSION}

Mechanisms to prevent desiccation stress include increased pigment synthesis in tissues such as carotenoids and anthocyanins, which protect photosynthetic

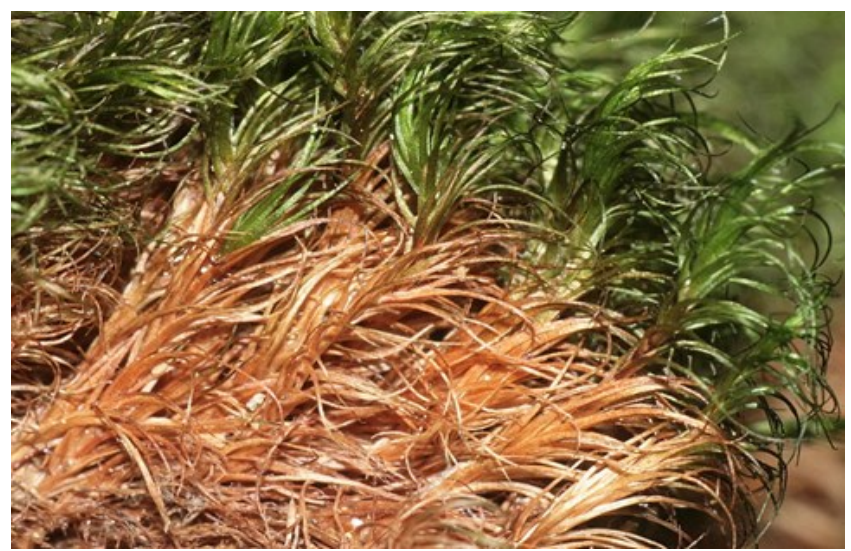

Fig. 1a. Fully hydrated thallus of C. flexuosus tissue from photoinhibition and photobleaching by reducing light intensity. Similarly, the tissues balance the formation of ROSs/free radicals.

\section{Level of relative water content}

Relative water content (RWC) was estimated in fully hydrated (Fig.1a), desiccated (Fig.1b) and rehydrated. The fresh intact total water content being at $100 \%$, the fresh weight was $0.421 \mathrm{~g}$. After $4 \mathrm{~h}$ of water loss by air dry, the weight of desiccated thallus was found to be $0.062 \mathrm{~g}$ and after rehydration, the weight was $0.315 \mathrm{~g}$. Therefore, the percentage of RWC after $4 \mathrm{~h}$ of desiccation and rehydration was found to be $25.2 \%$ and $85.2 \%$, respectively. The RWC \% in desiccated and rehydrated thalli reveals that $C$.flexuosus displays features of resurrection.

\section{Amount of chlorophyll and carotenoid content}

Reduced photosynthetic activities during desiccation were reported by many researchers (Yathisha et al., 2020; Banupriya et al., 2020). The present study, it was noticed that there was remarkable difference in Chl a and chl $b$ among hydrated, desiccated, and rehydrated thalli. The $\mathrm{Chl}$ a was decreased during desiccation from $12.4 \mu \mathrm{g} \mathrm{g}-1$ to $8.71 \mu \mathrm{g} \mathrm{g}^{-1}$, while chl $b$ increased $1.01 \mathrm{\mu g} \mathrm{g}^{-1}$ to $1.56 \mathrm{\mu g} \mathrm{g}^{-1}$. Upon rehydration, chlorophyll $a$ and chlorophyll $b$ contents regained to almost normal values of hydrated thallus, i.e., $12.4 \mathrm{\mu g} \mathrm{g}^{-1}$ and $1.1 \mathrm{\mu g} \mathrm{g}^{-1}$. The overall results suggest the recovery of major photosynthetic pigments during desiccationrehydration reaction. Interestingly, the increase in $\mathrm{Chl}$ $b$ further supports its role in photoprotection of $\mathrm{Chl}$ a during desiccation. Carotenoids content significantly increased during $4 \mathrm{~h}$ of desiccation, i.e., 0.251 (hydrated) to $0.514 \mathrm{\mu g} \mathrm{g}^{-1}$ (desiccated).

\section{$\mathrm{O}_{2} \cdot{ }^{-}$radical level}

Increased superoxide radical level was seen during the desiccation phase, i.e., the content of superoxide radical in hydrated thallus was $5.26 \mathrm{nmol} / \mathrm{g} \mathrm{FW}$, which was up-regulated in the desiccated thallus to $11.4 \mathrm{nmol} / \mathrm{g}$

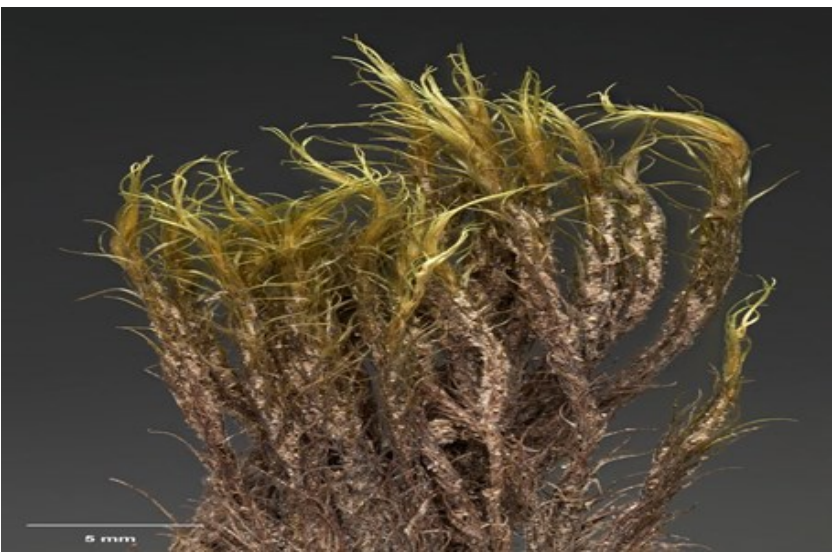

Fig.1b. Desiccated thallus of C.flexuosus 
FW (2 fold higher than hydrated condition). However, it recalled to $6.23 \mathrm{nmol} / \mathrm{g} \mathrm{FW}$ in the rehydrated condition, which was marginally higher than hydrated thallus. Enhanced superoxide radical level in desiccated thallus reflects the sign of oxidative stress which was indicated by the level of superoxide radical content in the thalli.

\section{Starch and sugar contents}

Resurrection plants protect their cell membrane during desiccation by enhancing the synthesis and storage of soluble sugars like sucrose and raffinose oligosaccharides (Farrant et al.,2009). Sucrose content was expressed as $\mu \mathrm{mol} / \mathrm{g} \mathrm{FW}$ and it increases in the desiccated and rehydrated thalli. The starch level in the desiccated thallus was decreased when compared to hydrated thallus.

Thus, the present study revealed that a decrease in starch content and increase in sucrose content might be due to the breakdown of the polysaccharides in the moss to sugar to counter desiccation. Also, increased sucrose concentration helps in maintaining the protein integrity during the period of severe water loss (Fig. 2).

\section{Proline content}

Accumulation of free amino acids has been recorded in many resurrection species to tide over desiccation stress (Pandey et al., 2010). Proline is an osmolyte and scavenger of reactive oxygen species (ROS), and also a molecular chaperone stabilizing the structure of proteins, thereby protecting the cells from damage due to oxidative stress. Proline levels in fully hydrated, desiccated and rehydrated were expressed in terms of $\mu \mathrm{mol} /$ $\mathrm{g} \mathrm{FW}$. It was clear that the proline level was remarkable during desiccation. In the hydrated stage, it was found to be $1.68 \mu \mathrm{mol} / \mathrm{g} \mathrm{FW}$ and in desiccated, it increased to $2.57 \mu \mathrm{mol} / \mathrm{g} \mathrm{FW}$ and during rehydration, it almost regained to $1.72 \mu \mathrm{mol} / \mathrm{g} \mathrm{FW}$. The results substantiate the role of proline in physiological specificity during desiccation.

\section{Lipid peroxidation (LPX)}

The major cellular molecules liable to damage by free radicals are polyunsaturated lipids (peroxidation of unsaturated fatty acids in cell membranes). LPX is an indicator of oxidative stress in response to desiccation which will result in damage to cell membranes and denaturation of enzymes, i.e., resulting in loss of cell viability. It was noticed that $0.692 \mathrm{nmol} \mathrm{g}{ }^{-1} \mathrm{FW}$ and 1.08 nmol g-1 FW in hydrated and desiccated, reflecting an uplift in LPX thus indicating the plausibility of cellular damage during oxidative stress. Furthermore, it reduced to $0.74 \mathrm{nmol} \mathrm{g-1} \mathrm{FW}$ in rehydrated as a resultant of the recovery events. The results indicated that membrane damage leads to the loss of membrane integrity due to desiccation stress (Fig. 3).

\section{Antioxidant enzymes}

Oxidative stress is a chain of biochemical reactions as a consequence of up-regulation of ROSs. ROS includes singlet oxygen $\left({ }^{1} \mathrm{O}_{2}\right)$, superoxide $\left(\mathrm{O}_{2}{ }^{-}\right)$, hydrogen peroxide $\left(\mathrm{H}_{2} \mathrm{O}_{2}\right)$, hydroxyl radical $(\mathrm{HO})$ and also reactive nitrogen species (RNSs). The generation of ROS due to desiccation may be lethal. Antioxidant machineries are triggered during the abiotic stress to counterbalance oxidative burst.

Oxidative stress is a deleterious event associated with a water deficit in plants. The present results reflected that anti-oxidation enzymes had been induced to balance desiccation damage via scavenging ROSs accumulation. Oxidative stress is a complex chain of reactions counterbalanced by antioxidant and nonantioxidant systems. The increased level of soluble sugars and proline content seen in the moss are examples of non-antioxidant system. SOD, CAT, POX and GR were examples of antioxidant systems in the moss. A decrease in chlorophyll content is thought to be linked to the protection of plants against UV light and damage due to oxygen free radical generation during desiccation. In the present study, chlorophyll content was reduced during desiccation but regained after rehydration. Chlorophyll $b$ content was enhanced in the desiccated stage, indicating that no complete dismantling of photosynthetic apparatus took place in water deficit $\left(1.01 \mu \mathrm{g} \mathrm{g}^{-1}\right.$ to $\left.1.56 \mu \mathrm{g} \mathrm{g}^{-1}\right)$. However, the chlorophyll a content in desiccated was lower than the control suggesting degradation probably occurred but was not severe (since the plant recovered the normal morphology and biochemical efficacies during rehydration). It must be noted that the higher carotenoid in desiccation state indicates the desiccation stress did not completely affect the photosynthesis ( 0.251 (hydrated) to 0.514 $\mu \mathrm{g} \mathrm{g}^{-1}$ (desiccated).

The activity of SOD was increased from 2.68 to 6.02 Units $\mathrm{mg}^{-1}$ protein from hydrated to desiccated thalli. The POX activity in hydrated thallus was $0.051 \mu \mathrm{mol}$ $\mathrm{min}^{-1} \mathrm{~g}^{-1}$ protein which was increased in desiccated to $0.12 \mu \mathrm{mol} \mathrm{min}^{-1} \mathrm{~g}^{-1}$ protein (Table 1 ). The GR activity

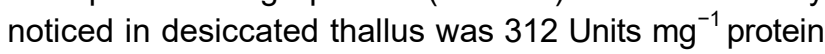
as compared to rehydrated thallus 287 Units $\mathrm{mg}^{-1}$ protein. The CAT activity, like other antioxidant enzymes, was found to be 0.369 units $/ \mathrm{mg}$ protein in desiccated thallus as compared to hydrated thalli $(0.168 \pm 0.02$ units/mg protein).

Almeselmani et al. (2009) correlated temperature stress among wheat genotypes with antioxidant defence enzymes. GR enzyme involves in balancing the reduced glutathione content in the cell system during abiotic stress. In the moss, the activity was more remarkable in the desiccated state, i.e., 312 Units $\mathrm{mg}^{-1}$ protein as compared to the heat stress in wheat $\left(67.8{\text { Units } \mathrm{mg}^{-1}}^{-1}\right.$ ). Das and Roychoudhury (2014) reported varied profile 
Usha, S. S. et al. / J. Appl. \& Nat. Sci. 13(4), 1407 - 1413 (2021)

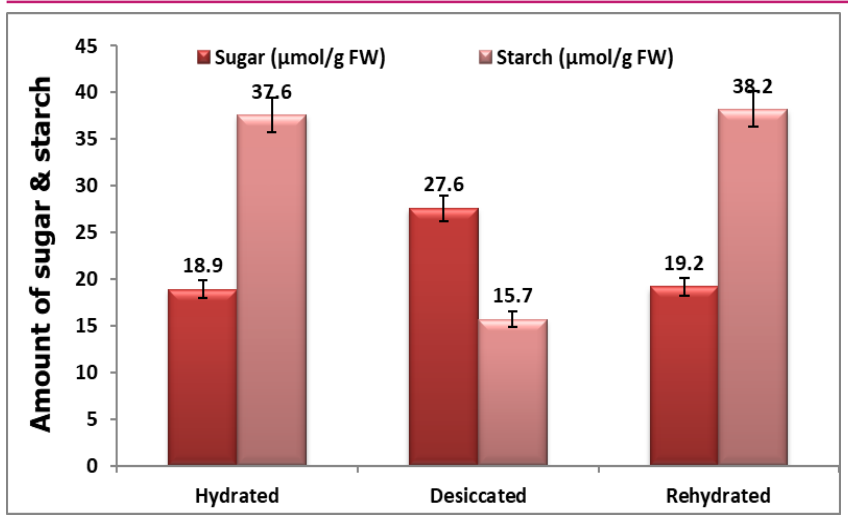

Fig. 2. Sugar and starch content ( $\mu \mathrm{mol} / \mathrm{g} F W$ ) in hydrated, desiccated and rehydrated thallus of C.flexuosus

levels of reactive oxygen species (ROS) and their response to antioxidants during environmental stress in plants. But, in the present study, a positive correlation was noticed between superoxide anion content and SOD enzyme activity. The enzyme SOD catalyzes the dismutation of the toxic free radical superoxide anion into less reactive oxygen species hydrogen peroxide, thus substantiating the efficacy of the msoos in terms of desiccation tolerance. Abbasi et al. (2016) reviewed the mechanism of salt tolerance and the role of potassium in its alleviation. Acosta-Motos et al. (2017) also documented plant responses to salinity stress and its enzymic adaptive mechanisms. In the present analysis, water loss in the moss induced oxidative stress reflected in superoxide anion content and lipid peroxidation levels. But, interestingly, the moss species ameliorated the oxidative stress via the osmolyte content (sugar and proline) and AOX enzymes.

Wang et al. (2010) proved this in the resurrection species Selaginella tamariscina. Deeba et al.(2009) established the balancing role of antioxidant enzymes such as CAT, SOD, and GR in S. bryopteris. As compared to $S$. bryopteris the activity profile of the AOX enzymes displayed by the moss species was less. Lubaina et al. (2016) and Kavitha \& Murugan (2016) in Adiantum latifolium and Dicranopteris linearis confirmed the role of CAT, SOD, and GR and POX activity under dehydrated and hydrated conditions using synthetic dehydrating agent polyethylene glycol. In the present study, C.flexuosus was desiccated under natural conditions,

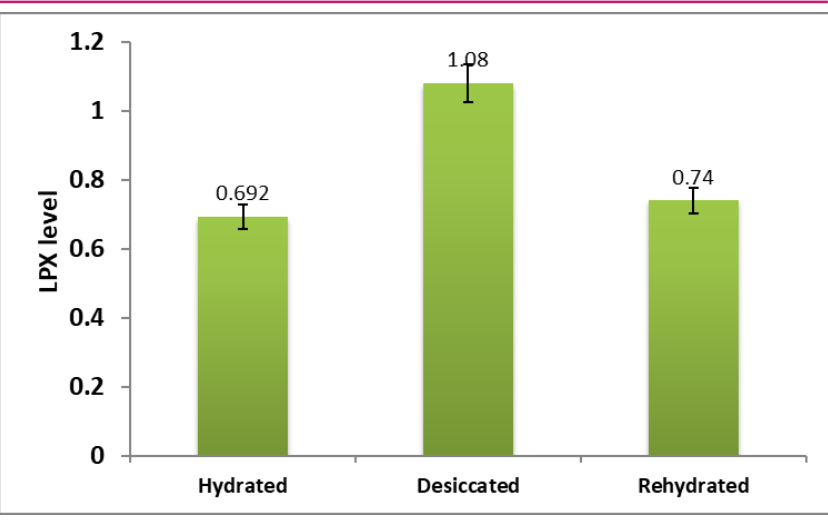

Fig. 3. LPX level (nmol/g FW) in hydrated, desiccated and rehydrated thallus of C.flexuosus

reflected the uplifting of the above enzyme activities and regained the normal morphology during rehydration (Table 1). Desoky El-Sayed et al. (2021) and Burnett et al. (2021) analyzed ionic, osmotic and oxidative stress factors towards salinity tolerance in barley. In their study the enzyme CAT was displayed much meager activity when compared to the moss species i.e., $0.369 \pm 0.04$ (desiccated) vs $0.075 \mathrm{U} \mathrm{mg} /$ protein. Thus, the moss bioengineered the tolerance power during water stress. Antioxidant responses under salinity and drought in three closely related wild monocots with different ecological regimes have been correlated (Al Hassan et al., 2017). In their study, POX showed more response as compared to CAT enzyme. Contradictorily, in the present study CAT was more active in the moss species than POX enzyme (Table 1). Allel et al.(2019) evaluated salinity tolerance indices in terms of sugar and proline content in the North African barley accessions at the reproductive stage. The present data of osmolytes such as sugar $(27.6 \mu \mathrm{mol} / \mathrm{g} \mathrm{FW})$ and proline $(2.57 \mu \mathrm{mol} / \mathrm{g} \mathrm{FW})$ was more or less at par with the barley species. Behrouzi et al. (2015) analyzed catalase and peroxidase antioxidant enzyme activities in barley cultivars seedling under salt stress and the obtained data was lower than the moss species. POX and CAT enzymes peroxidatively or catalytically oxidize hydrogen peroxide into water or water and oxygen, respectively.

Ben Chikha et al. (2016) compared barley landrace genotypes with contrasting salinity tolerance at the

Table 1. SOD (Units mg-1 protein), POX $\mu \mathrm{mol}$ min-1 g-1 protein , GR (Units mg-1 protein ) and CAT (Units mg-1 protein) activities in hydrated, desiccated and rehydrated thallus of C.flexuosus

\begin{tabular}{lllll}
\hline & $\begin{array}{l}\text { SOD } \\
\text { (Units } \mathbf{m g - 1} \text { protein })\end{array}$ & $\begin{array}{l}\text { POX } \\
\boldsymbol{\mu m o l} \text { min-1 } \mathbf{~ g - 1} \text { protein }\end{array}$ & $\begin{array}{l}\text { GR } \\
\text { (Units mg-1 protein ) }\end{array}$ & $\begin{array}{l}\text { CAT } \\
\text { (Units mg-1 protein) }\end{array}$ \\
\hline Hydrated & $2.68 \pm 0.021$ & $0.051 \pm 0.0090 .0054$ & $167 \pm 0.86$ & $0.168 \pm 0.02$ \\
Desiccated & $6.02 \pm 0.042$ & $0.12 \pm 0.0032$ & $312 \pm 0.54$ & $0.369 \pm 0.04$ \\
Rehydrated & $3.02 \pm 0.03$ & $0.071 \pm 0.005$ & $287 \pm 0.92$ & $0.211 \pm 0.01$ \\
\hline
\end{tabular}


vegetative growth stage. In their study, the enzymes showed high profound of activity at matured stage than juvenile condition. Ben Khaled et al. (2012) evaluated salt tolerance of 14 wild landraces of barley genotypes from southern Tunisia using multiple parameters. In the present study, the primitive moss species displayed remarkable recovery during rehydration suggests its tolerance to water stress. Bornare et al. (2013) compared biochemical indicators of salinity tolerance of barley with other crops. The AOX enzyme displayed by the moss species strongly suggests that these enzymes may be used as bioindicators of oxidative stress in plants.

Hasanuzzaman et al. (2013) explained the physiological, biochemical, and molecular mechanisms of heat stress tolerance in plants. Zhang et al. (2015) narrated the clones of FeSOD, MDHAR, DHAR genes from Trifolium repens and gene expression analysis of ROS-scavenging enzymes during abiotic stress and hormone treatments. The overall data obtained in the present analysis require a further extension in terms of identifying the isozyme profile of SOD enzymes and tracing the Asada Halliwell cycle. Khalvandi et al. (2021) reported drought tolerance signalling networks of desiccation in potato species induced by salicylate with carbon assimilation features and leaf proteins in winter variety wheat. The data of AOX enzyme protein activity in the moss species during water loss stress and the rejuvenating caliber of the species warrant future study at molecular levels to substantiate the drought tolerance of the species.

\section{Conclusion}

The results point out that $C$. flexuosus is a desiccation -tolerant species which regains complete physiological and biochemical activities after rehydration. The moss tide over water deficit by up-regulation antioxidant enzymes such as SOD, POX, CAT and GR, thereby mitigating oxidative stress in the leafy thallus. The amount of superoxide anion and the level of LPX increased during desiccation were regained to normal during rehydration. Chlorophyll $b$ and carotenoid were functioning like sunscreen and protect the chlorophyll a from photooxidation. Similarly, soluble sugars and proline function as signalling molecules and function as an osmolyte in regulating abiotic stress. Therefore, the present study confirms the mechanisms underlying desiccation tolerance in the moss species. Future studies are warranted at the molecular level to elucidate the genes linked with this mechanism in the species.

\section{Conflict of interest}

The authors declare that they have no conflict of interest.

\section{REFERENCES}

1. Abbasi, H., Jamil, M., Haq, A., Ali, S., Ahmad, R., Malik, Z.\& Veen, P. (2016). Salt stress manifestation on plants, mechanism of salt tolerance and potassium role in alleviating it: a review. Zemdirbyste Agriculture 103, 229 238.

2. Acosta-Motos, J.R., Ortuño, M.F., Bernal-Vicente, A., Diaz -Vivancos, P., Sanchez Blanco, M.J. \&Hernandez J.A. (2017). Plant responses to salt stress: adaptive mechanisms. Agronomy, 7, 3390.

3. Ahanger, M.A., Siddique, K.H.M. \& Ahmad, P. (2021). Understanding drought tolerance in plants. Drought Tolerance e172 (2), 286-288

4. Al Hassan, M., Chaura, J., Donat-Torres, M.P., Boscaiu, M.\& Vicente, O. (2017). Antioxidant responses under salinity and drought in three closely related wild monocots with different ecological optima. AoB Plants 1-20.

5. Allel, D., BenAmar, A., Badri, M. \&Abdelly C. (2019). Evaluation of salinity tolerance indices in North African barley accessions at reproductive stage. Czech Journal of Genetics and Plant Breeding 55, 61-69.

6. Almeselmani, M., Deshmukh, P. S. \& Sairam, R. K (2009). High temperature stress tolerance in wheat genotypes: role of antioxidant defence enzymes. Acta Agronomica Hungarica. 57: 1-14.

7. Banupriya, T .G., Devaraja Akash, C. R., Yathish, N. S. \& Sharthchandra, R. G .(2020). Studies on the mechanism of desiccation tolerance in the resurrection fern Adiantum raddianum Journal of Applied Biology \& Biotechnology Vol. 8(01), 6-14,

8. Behrouzi, M., Valizadeh, M. \& Vahed, M.M. (2015). Catalase and peroxidase antioxidant enzyme activities in barley cultivars seedling under salt stress. Bulletin of Environmental Pharmacology Life Science 4, 29-35.

9. Ben Chikha, M., Hessini, K., Ourteni, R.N., Ghorbel, A\& Zoghlami, N. (2016). Identification of barley landrace genotypes with contrasting salinity tolerance at vegetative growth stage. Plant Biotechnology 33:287-295.

10. Ben Khaled, A., Hayek, T., Mansour, E., Hannachi, H., Lachiheb, B. \& Ferchichi, A. (2012). Evaluating Salt tolerance of 14 barley genotypes from southern Tunisia using multiple parameters. Journal of Agriculture Sciences 4, 27 -38 .

11. Bornare, S.S., Prasad, L.C. \& Kumar, S. (2013). Comparative study of biochemical indicators of salinity tolerance of barley (Hordeum vulgare L.) with other crops: a review. Canadian Journal of Plant Breeding 1:97-102.

12. Burnett, A.C., Serbin, S.P., Davidson, K.J., Ely, K.S. \& Alistair Rogers. (2021). Detection of the metabolic response to drought stress using hyperspectral reflectance. Journal of Experimental Botany 72(18), 6474 6489. https://doi.org/10.1093/jxb/erab255

13. Change, B. \& Maethly, A.C., (1995). Assay of catalases and peroxidase. Methods in Enzymology, 2, 764-775.

14. Das, K. \& Roychoudhury, A. (2014). Reactive oxygen species (ROS) and response of antioxidants as ROS-scavengers during environmental stress in plants. Frontiers in Environmental Science 2,53.

15. de Carvalho,R., Maurício, A., Franscisco Pereira, M., Marques da Silva, J. \& Branquinho, C. (2019). All for One: The Role of Colony Morphology in Bryophyte Desiccation 
Usha, S. S. et al. / J. Appl. \& Nat. Sci. 13(4), 1407 - 1413 (2021)

Tolerance. Frontiers in Plant Science. 10:1360-1368

16. Deeba, F., Pandey, V., Pathre, U. \& Kanojiya, S. (2009). Proteome analysis of detached fronds from a resurrection plant Selaginella bryopteris- response to dehydration and rehydration. Journal of Proteomics and Bioinformatics, 2,108-16.

17. Desoky El-Sayed, M., Mansour Elsayed, El-Sobky, ElSayed, E.A., Abdul-Hamid Mohamed, I., Taha Taha, F., Elakkad Hend, A.., Arnaout Safaa, M. A. I., Eid Rania, S. M., El-Tarabily Khaled, A. \& Yasin Mohamed A.T. (2021). Physio-biochemical and agronomic responses of faba beans to exogenously applied nano-silicon under drought stress conditions. Frontiers in Plant Science 12, 19021910 DOI=10.3389/fpls.2021.637783

18. Farrant, J. M., Lehner, A., Cooper, K. \& Wiswedel, S. (2009). Desiccation tolerance in the vegetative tissues of the fern Mohria caffrorum is seasonally regulated.The Plant Journal 57, 65-79. doi: 10.1111/j.1365313X.2008.03673.x

19. Fontana, L.M.\&Rosei, M.A. (2001). Interaction of enkephalins with oxyradicals. Biochemical Pharmacology, 61 (10), 1253-7

20. Gao, B., Zhang, D., Li, X., Yang, H., Liang, Y., Chen, M., Zhang, Y., Zhang, J. \& Andrew, W. (2018). Desiccation tolerance in bryophytes: the rehydration proteomes of Bryum argenteum provide insights into the resuscitation mechanism. Journal of Arid Land, 10, 152-167. https:// doi.org/10.1007/s40333-017-0033-3

21. Halliwell, B. \& Foyer, C.H. (1978). Properties and physiological function of a glutathione reductase purified from spinach leaves by affinity chromatography. Planta,139, 917.

22. Hasanuzzaman, M., Nahar, K., Alam, M.M., Roychowdhury, R.\& Fujita, M. (2013). Physiological, biochemical, and molecular mechanisms of heat stress tolerance in plants. International Journal of Molecular Sciences 14,9643-9684

23. Kavitha, C. H.\& Murugan. K. (2016). Dissimilitude response of peroxidases of Dicranopteris linearis (Burm.F.) Underw. against desiccation and rehydration stress. IOSR Journal of Biotechnology and Biochemistry; 2, 36-41

24. Khalvandi, M., Siosemardeh, A., Roohi, E. \& Keramati, S.
(2021). Salicylic acid alleviated the effect of drought stress on photosynthetic characteristics and leaf protein pattern in winter wheat. Heliyon, 7(1), e05908. https:// doi.org/10.1016/j.heliyon.2021.e05908

25. Li, H.S., Sun, Q., Zhao, S.J., Zhang, W.H. (2000).In Principles and Techniques of Plant Physiological Biochemical Experiment. Higher Education Press Beijing, China.

26. Lubaina, A.S., Brijithlal, N.D.\& Murugan. K. (2016).Unravelling desiccation and rehydration tolerance mechanism in the fern, Adiantum latifolium. Bioscience Biotechnology Research Communications, 9(4), 672-9.

27. Pandey, V., Ranjan, S., Deeba, F., Pandey, A.K., Singh, R., Shirke, P.A. \& Pathre, U.V. (2010). Desiccationinduced physiological and biochemical changes in resurrection plant, Selaginella bryopteris. Journal of Plant Physiology, 167, 1351-1359

28. Porra, R.J., Thompson, W.A. \& Kriedemann, P.E. (1989). Determination of accurate extinction coefficients and simultaneous equations for assaying chlorophylls $a$ and $b$ extracted with four different solvents: Verification of the concentration of chlorophyll standards by atomic absorption spectroscopy. Biochimica et Biophysica Acta (BBA)Bioenergetics.975(3),384-94.

29. Wang, X., Chen, S., Zhang, H., Shi L., Cao. F, Guo .L. (2010).Desiccation tolerance mechanism in resurrection fern-ally Selaginella tamariscina revealed by physiological and proteomic analysis. Journal of Proteome Research 9, 6561-77.

30. Wood, A. J. (2007). The nature and distribution of vegetative desiccation-tolerance in hornworts, liverworts and mosses. Bryologist, 110, 163-177.

31. Yathisha, N. S., Barbara,P., Gügi,B., Yogendra, K ., Jogaiah,S., Azeddine,D.\& Sharatchandra, R. G. (2020). Vegetative desiccation tolerance in Eragrostiella brachyphylla: biochemical and physiological responses Heliyon, 6 e04948

32. Zhang, Y., Li ,Z., Peng ,Y., Wang , X., Peng , D., Li , Y., He, X., Zhang, X., Ma , X., Huang, L.\& Yan,Y. (2015). Clones of FeSOD, MDHAR, DHAR genes from white clover and gene expression analysis of ROS-scavenging enzymes during abiotic stress and hormone treatments. Molecule, 20, 20939-20954. 